\title{
A University hospital healthcare workers' high-risk contact with patients diagnosed with coronavirus disease (COVID-19): a cross- sectional evaluation
}

Bir üniversite hastanesinde sağlık çalışanlarının COVID-19 tanılılar ile yüksek riskli temasları: Kesitsel bir değerlendirme

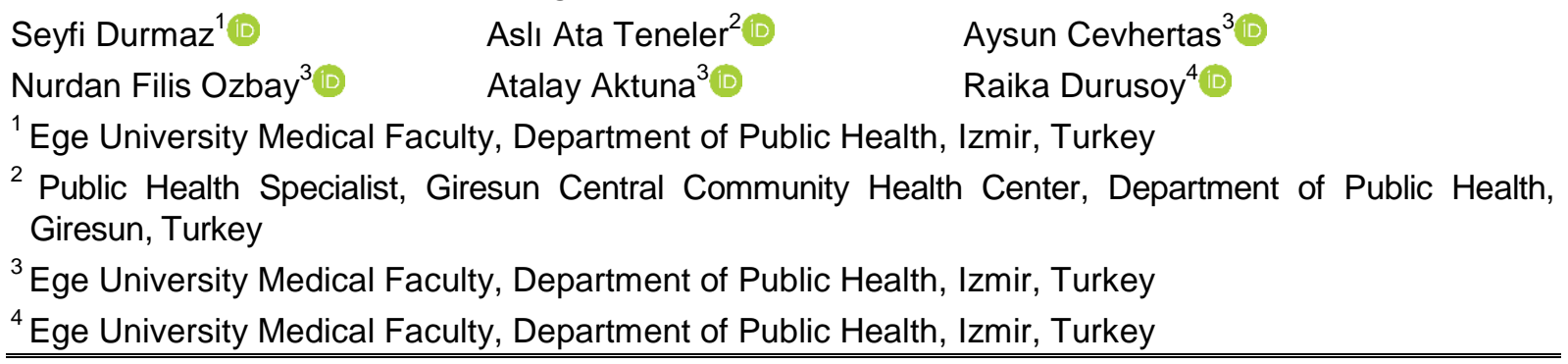

\section{ABSTRACT}

Aim: This study aimed to determine the risk level of contact with COVID-19 positive patients among healthcare workers (HCW) at a university hospital in Turkey and to demonstrate the factors associated with high-risk contact.

Materials and Methods: This cross-sectional study included all contacts from March 11 to May 31, 2020. Risk contact status (High / Medium / Low) was the dependent variable. Independent variables are defined on the basis of personal characteristics, occupational health and safety data and communication data. Logistic regression analysis was performed to determine the adjusted relationships all the significant variables found using chi-square and student's $t$ tests with the dependent variable.

Results: A total of 1043 contacts were included. Taking COVID-19 clinics as a reference, other clinics and areas outside the clinics were found to involve 1.57-fold [95\% $\mathrm{Cl}: 1.10-2.22]$ and 2.20 -fold (95\%Cl:1.22-3.96) higher risk of exposure, respectively. The contact of HCW with each other was found to pose a 5.78-fold (95\% $\mathrm{Cl}: 4.07-8.20)$ higher risk, whereas nonhospital settings posed a 13.34fold (95\% Cl:5.24-33.96) higher risk than contact with patients.

Conclusion: The fact that high-risk contact was less common among the frontline sites and HCW's can be interpreted as an indicator that HCW have improved themselves in terms of the use of personal protective equipment and infection control measures.

Keywords: COVID-19, healthcare workers, contact tracing, high-risk exposure, occupational health and safety.

This study was presented at the $4^{\text {th }}$ International, $22^{\text {nd }}$ National Public Health Congress which was held online between 13-19 December 2020. The abstract paper has been published in the congress booklet.

\footnotetext{
Corresponding author: Aslı Ata Teneler

Public Health Specialist, Giresun Central Community Health

Center, Department of Public Health, Giresun, Turkey

E-mail: aslivamta@gmail.com

Application date: 26.03.2021

Accepted: 20.05.2021
} 


\section{öz}

Amaç: Bu çalışmada, pandemi sırasında Türkiye'de bir üniversite hastanesindeki sağlık çalışanlarının koronavirüs (COVID 19) pozitif hastalarla temaslarına bağlı risk düzeylerinin belirlenmesi ve sağlık çalışanları arasında yüksek riskli temasla ilişkili faktörlerin ortaya konması amaçlanmıştır. Gereç ve Gereç ve Yöntem: Kesitsel tipteki bu çalışma, Ege Üniversitesi Tıp Fakültesi Hastanesinde 11 Mart 31 Mayıs 2020 tarihleri arasında sağlık çalışanları ile COVID-19 hastaları arasındaki tüm temasları içermektedir. Riskli temas durumu (Yüksek/Orta/Düşük) bağımlı değişken olarak alınmıştır. Kişisel özellikler, iş sağı̆̆ı ve güvenliği verileri ve iletişim verileri bağımsız değişkenler olarak tanımlanmıştır. Tüm tanımlayıcı değişkenlerin bağımlı değişkenle olan ilişkisi Ki-kare ve Student's $t$ testleri ile araştırılmıştır. Açıklayıcı değişkenlerin bağımlı değişken ile düzeltilmiş ilişkilerini belirlemek amacıyla lojistik regresyon analizi uygulanmıştır.

Bulgular: Toplam 1043 temaslı çalışmaya dahil edilmiştir. COVID-19 klinikleri referans alınarak, diğer kliniklerin ve kliniklerin dışındaki alanların 1,57 kat [\%95 Cl: 1,10-2,22] ve 2,20 kat (\% 95 Cl: 1,223,96) daha yüksek maruz kalma riski içerdiği bulunmuştur. Sırasıyla sağlık çalışanlarının birbirleriyle teması 5,78 kat (\%95 Cl: 4,07-8,20) daha yüksek risk oluştururken, hastane dışı ortamlar hastalarla temastan 13,34 kat (\%95 Cl: 5,24-33,96) daha yüksek risk oluşturmuştur.

Sonuç: Yüksek riskli temasın ön saflarda ve sağlık çalışanları arasında daha az yaygın olması, sağlık çalışanlarının kişisel koruyucu ekipman kullanımı ve enfeksiyon kontrol önlemleri açısından kendilerini geliştirdiklerinin bir göstergesi olarak yorumlanabilir.

Anahtar Sözcükler: Koronavirüs hastalığı, sağlık çalışanları, temaslı izlem, yüksek riskli temas, iş sağıı̆ı ve güvenliği.

Bu çalışma, 13-19 Aralık 2020 tarihleri arasında online olarak gerçekleştirilen 4. Uluslararası 22. Ulusal Halk Sağı̆ğı Kongresi'nde sunulmuştur. Özet bildiri, kongre kitapçığında yayınlanmıştır.

\section{INTRODUCTION}

Current evidence suggests that COVID-19 is transmitted from person to person by close contact and droplets. Hospital environment is important in terms of secondary transmission of COVID-19. Therefore, healthcare workers constitute the most risky occupational group in terms of exposure to the disease (1). The difficult working conditions that arise as a result of the pandemic show that it may increase the risk of nosocomial SARS-CoV-2 infection among healthcare professionals. According to the reports published in April, the proportion of healthcare workers among all positive cases was $9 \%$ in Italy (2), $4 \%$ in China, and $13.6 \%$ in Spain (3). On April 29, 2020, the proportion of healthcare workers among all individuals who were found to be positive was reported to be $6.5 \%$ in Turkey (2). The rate of positive cases among healthcare professionals vary: In a study conducted in the Netherlands, $6.4 \%$ of healthcare workers tested positive (4). The rate of positive healthcare workers at Tongji Hospital in Wuhan was $1.1 \%$ (5). In Spain, this rate was reported to be $1 \%(3)$. While studies in this field are yet limited in Turkey, $1 \%-9 \%$ of all healthcare workers are currently positive (6). For EUMF Hospital, this rate was $1.1 \%$ with 65 polymerase chain reaction (RT-PCR)-positive cases.

$A$ rapid increase in infection among healthcare workers can lead to high morbidity and mortality rates. Therefore, the protection of healthcare workers from COVID-19 infection is one of the important priorities. Taking personal preventive measures in hospitals, isolating positive cases, detecting those who have contacted COVID-19positive patients and isolating those with high-risk exposure are among the important strategies to reduce the risk of infection among healthcare workers (7). The aim of rapidly identifying and tracing the contacts of possible or confirmed COVID-19 cases is to prevent secondary transmission that may occur after the first detected transmission. Early detection and isolation of healthcare workers with high risk of exposure to COVID-19, as well as supporting self-monitoring for fever and other symptoms limits the spread of COVID-19 by healthcare staff (8).

Healthcare workers who come into contact with COVID-19-positive patients in Turkey are categorized according to the personal measures they took as per the procedure performed, as 
well as the duration of contact, and distance from the patient, and monitoring is done in accordance with the risk groups. Healthcare worker is considered to have high-risk contact if there was direct contact with a COVID-19-positive patient or the patient's respiratory secretions, or if the healthcare worker has stayed indoors for $>15 \mathrm{~min}$ at a distance closer than $1 \mathrm{~m}$ to a positive patient without personal protective equipment (PPE) $(9,10)$. In the early days of the pandemic, healthcare workers who had been in contact with COVID-19-positive patients in Turkey were evaluated by community-based classification as "those who had close contact or contact" whereas the algorithm "Evaluation of Healthcare Workers with COVID-19 Exposure," which was prepared in accordance with international references in which PPE use is also questioned (11), has been in use for monitoring as of April 6, and the said algorithm was also updated throughout the process (1). Contact with COVID19-positive patients within the time period covering $48 \mathrm{~h}$ before and 14 days after the onset of symptoms (PCR positivity if no symptoms are present) are taken into consideration (2).

The WHO has defined the contact of healthcare workers with each other and with the patients as a risk factor for nosocomial COVID-19 infections (12). In a study of 2,994 contacts of 144 cases in Hangzhou, China, it was found that the highest risk of developing the disease was observed in the healthcare facility with an increase of 3.6-fold in the said risk. It was also shown that the risk of developing the disease varied among those who had contact, depending on the location and nature of the contact (e.g. during meals or in the same vehicle) (13). Studies show that the risk of developing COVID-19 in healthcare workers varies depending on whether the transmission occurred between the workers themselves or from the patients or family. In a retrospective study evaluating healthcare workers in terms of risk, it was shown that the risk changed depending on whether the source of transmission was at the hospital or in the family environment (14). Another study showed that the differences between occupational groups led to varying risk status (15). However, studies conducted on highrisk contact groups are limited in number. Although the importance of contact monitoring is known, studies aimed at determining the risk factors for high-risk contact with COVID-19positive patients will be able to offer opportunities to healthcare professionals in terms of managing the pandemic.
Identifying the predisposing factors among highrisk healthcare workers will be useful to understand the ways to protect workers from nosocomial infection. Thus, the hospital management, employee health unit or infection control committee can prevent unnecessary COVID-19 infections and their complications, quarantine practices and loss of health care workforce by making appropriate arrangements to prevent contamination, planning practices and determining return to work strategies. This study aimed to determine the risk level of contact with COVID-19-positive patients among healthcare workers at a university hospital during the pandemic and to demonstrate the factors associated with high-risk contact.

\section{MATERIALS and METHODS}

\section{Study group}

The study was designed as cross-sectional research. It included the contact data of healthcare workers who had contact with COVID19-positive cases between March 11 and May 31, 2020, at EUMF Hospital is located in Izmir with 5800 employees and 1757 hospital beds, which is a reference hospital for Aegean Region. The study population consisted of all healthcare workers at EUMF hospital who had been in contact with COVID-19 RT-PCR-positive cases in the period from the announcement of the pandemic to the declaration of normalization. All contacts that were recorded after detection by the ÇASAGÜB Surveillance Team as per the criteria of the Turkish Ministry of Health among the EUMF employees aged $>18$ years were included in the study. Contacts of cases that were found to be falsely positive, non-healthcare workers who had contact, and those whose contact data was inaccessible were excluded from the study (Figure-1).

\section{Variables}

In terms of contact evaluation, healthcare workers who had face-to-face contact for $>15 \mathrm{~min}$ at a distance closer than 1 meter without any Personal Protective Equipment (PPE) with cases diagnosed with COVID-19 (before the occurrence of symptoms or within 2 days before sample collection and until patients satisfy the isolation termination criteria), unprotected physical contact with the patient or infected material, and who stayed in environments where aerosol-generating procedures are performed without complete protection were considered as healthcare 
workers with "high-risk exposure." Situations involving other contacts with cases with COVID19 for $<15$ min or at a distance longer than 1 meter and cases where both parts used PPE were defined as "low-risk exposure" (2, 11, 16, 17).

Those who had contact with COVID-19-positive cases were investigated in terms of personal characteristics, such as sex, age, and occupation; as well as contact characteristics such as the presence of chronic diseases, status of training for risks in the working environment in 2019, situations that represent occupational health and safety such as experiencing occupational accidents in the last year (March 2019 - March 2020); contact location, i.e. COVID-19 clinics/non-COVID-19

environments; contact source, i.e. Patient/Healthcare worker/Non-hospital; and the number of contacts (first contact/repeated contact).

\section{Data collection}

A form that consisted of 20 questions was created including the variables used by the research team. This form was filled in with the contribution of surveillance records, routine records of ÇASAGÜB, and interviews with the participants.

Surveillance records: With the detection of the first case, a surveillance study group consisting of one public health faculty member and 12 public health physicians was formed. This group performed their work within ÇASAGÜB. The team worked in alternating order and maintained continuity. In a maximum of $24 \mathrm{~h}$, case contacts were reached by phone or face-to-face interviews. The personal characteristics and contact details of those who had contact were questioned, contact risk classification was made, and the healthcare workers included in the highrisk group were isolated.

ÇASAGÜB records: All instructions, trainings, environmental risk assessments, health supervision and occupational accident procedures performed by an average of 14 employees working on employee health and safety at EUMF hospital are regularly registered. Data on healthcare workers' chronic illness status, previous occupational accidents, and educational activities were obtained from these records.

In case of need, the employees who were on the list of those who had contact with COVID-19positive cases were reached by phone to update the data.

\section{Analysis}

SPSS version 23.0 (SPSS Inc., Chicago, IL, USA) software was used for data analysis. Descriptive data was analyzed using frequency, mean, and median values. When using the risk status in analysis, the low and moderate risk groups defined by the Ministry of Health were combined using the Centers for Disease Control and Prevention and WHO guidelines (2, 11, 16, 17). Chi-square and Student's t-tests were used to examine the relationships between risk status and individual factors, demographic characteristics, health characteristics, working conditions, and contact characteristics. Logistic regression analysis was performed to determine the corrected relationship of all descriptive variables with the dependent variable. The level of significance was set at 0.05 .

\section{Ethics}

The study was first approved by the Turkish Ministry of Health (Number: 2020-0604T12_10_55). The approval of the chief physician was obtained for the use of hospitalbased data. Ethical approval was obtained from the Ethics Committee for Medical Research of EUMF Hospital (Number: 20-6.1T/36). During the pandemic all contact tracing process were carried out in accordance with relevant guidelines and regulations of Turkish Ministry of Health. The Occupational Health and Safety Unit is an institution that has to publish periodic official reports, thus each contact with the unit thus contains an approval. As most of the contact tracing data was collected through telephone interviews, verbal approval was taken from the participants.

\section{RESULTS}

A total of 1070 contact interviews were conducted with healthcare workers by the Surveillance Team of EUMF Hospital between March 11 and May 31, 2020, wherein 1043 contact cases of 843 healthcare workers were included in the study. Nine interviews were excluded from the data since the cases were identified as false positive and 17 were excluded due to absence of contact. A participant was not included in the evaluation due to lack of data (Figure-1). Furthermore, $14.54 \%$ of the healthcare workers at the hospital were registered as those who had contact during this period, and $31.45 \%$ of the contacts were considered to have high-risk exposure (Table-1). 


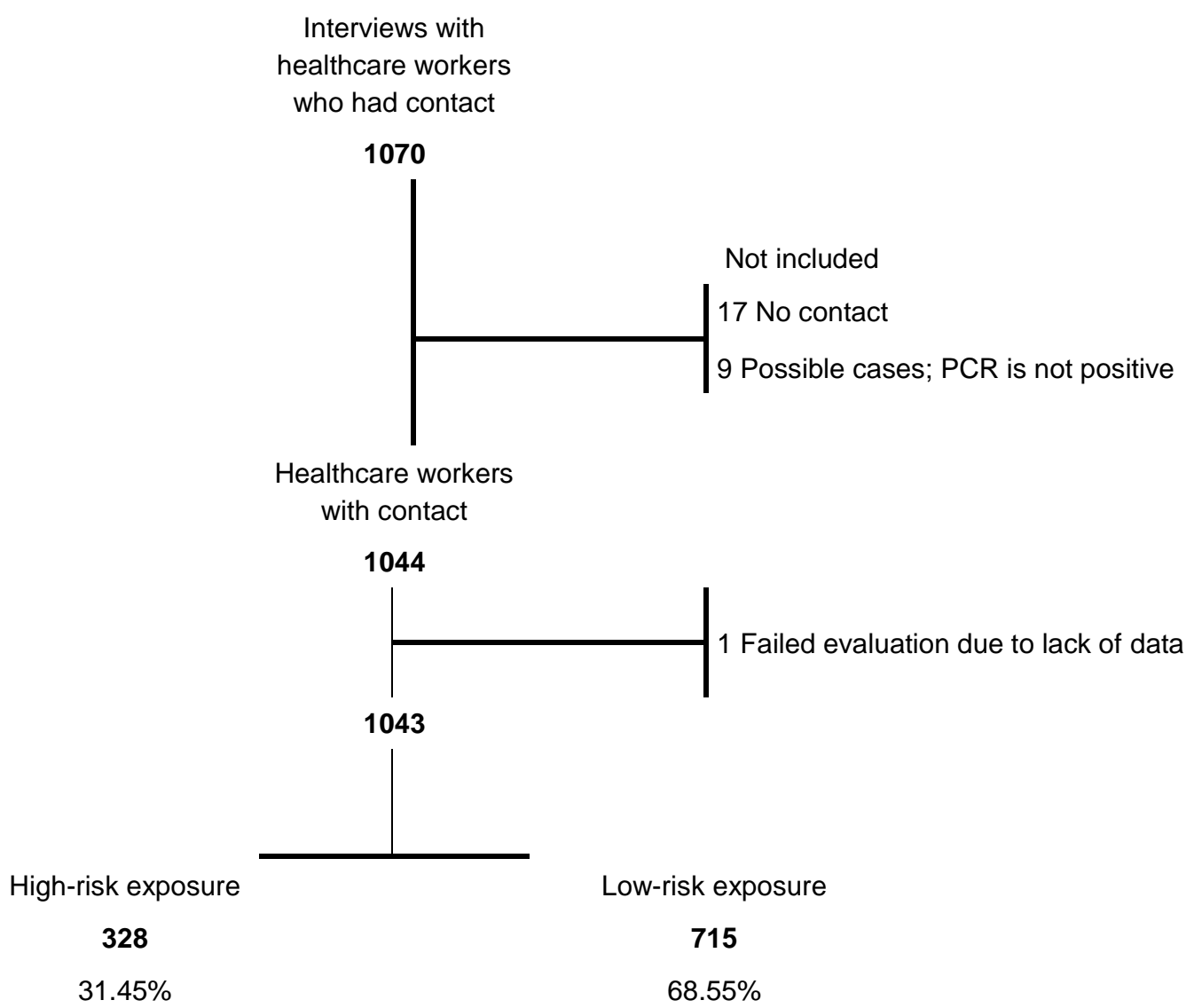

Figure-1. Hospital Healthcare Workers Contact Flowchart.

The mean age of those who had contact with COVID-19-positive cases was $35.80 \pm 8.25$ years in this study. Of those who had contact, $57.43 \%$ were female and $64.27 \%$ provided frontline healthcare services, of whom $24.95 \%$ were physicians, $19.77 \%$ were nurses, and $29.27 \%$ were healthcare support workers. Furthermore, $43.20 \%$ of those who had contact had a chronic disease and $19.77 \%$ reported an occupational accident in the last year; $10.55 \%$ received an occupational health and safety training in the last year (Table-1). Next, $37.00 \%$ of those who had contact experienced exposure in COVID-19 clinics, whereas $19.77 \%$ had repeated contact with infected patients; $52.02 \%$ of the contact events occurred between healthcare workers (Table-1).

There was a significant relationship between the contact risk status and the type of service (occupation) provided at the time of exposure, contact source, contact location, and number of contacts $(p<0.05)$.
Considering all associated factors, age, and sex and taking COVID-19 clinics as a reference in corrected analyzes, other clinics and hospital areas outside the clinics were found to involve 1.57 -fold [95\% confidence interval (Cl): 1.10 2.22] and 2.20 -fold (95\% Cl: 1.22-3.96) higher risk of exposure to COVID-19, respectively. Taking patients as a reference, the contact of healthcare workers with each other was found to pose a 5.78-fold (95\% Cl: 4.07-8.20) higher risk, whereas nonhospital settings posed a 13.34-fold (95\% Cl: 5.24-33.96) higher risk. Healthcare support workers had a 1.80 -fold $(95 \% \mathrm{Cl}$ : $1.27-$ 2.56) higher risk of exposure to COVID-19 than those who provided frontline healthcare services (physicians and nurses). Healthcare workers who had the first risky contact were found to have a 1.56 -fold (95\% Cl: 1.04-2.34) higher contact risk than those who had repeated contact (Table-2). 
Table-1. Contact risk distribution of healthcare workers who had contact COVID-19 and characteristics of the group.

\begin{tabular}{|c|c|c|c|c|c|c|c|}
\hline \multirow{2}{*}{ CHARACTERISTICS } & \multicolumn{2}{|c|}{ TOTAL* } & \multicolumn{2}{|c|}{ HIGH RISK } & \multicolumn{2}{|c|}{ LOW RISK } & \\
\hline & $n$ & $\%^{*}$ & $\mathbf{n}$ & $\% *$ & $\mathbf{n}$ & $\% *$ & \\
\hline AGE (years) & 1040 & & 326 & & 714 & & 0.263 \\
\hline$<40$ & 717 & 68.94 & 217 & 66.56 & 500 & 70.03 & \\
\hline$\geq 40$ & 323 & 31.06 & 109 & 33.44 & 214 & 29.97 & \\
\hline SEX & 1043 & & 328 & & 715 & & 0.853 \\
\hline Female & 599 & 57.43 & 187 & 57.01 & 412 & 57.62 & \\
\hline Male & 444 & 42.57 & 141 & 42.99 & 303 & 42.38 & \\
\hline TYPE OF SERVICE PROVIDED (OCCUPATION) & 1042 & & 327 & & 715 & & 0.001 \\
\hline Frontline healthcare & 668 & 64.11 & 182 & 55.66 & 486 & 67.97 & \\
\hline a. Physician & 260 & 24.95 & 77 & 23.56 & 183 & 25.59 & \\
\hline b. Nurse & 357 & 19.77 & 96 & 29.36 & 261 & 36.51 & \\
\hline c. Other healthcare workers & 51 & 4.89 & 9th & 2.75 & 42nd & 5.87 & \\
\hline Healthcare support & 305 & 29.27 & 113 & 34.56 & 192 & 26.85 & \\
\hline a. Support worker & 305 & 29.27 & 113 & 34.56 & 192 & 26.85 & \\
\hline Technical service & 69 & 6.62 & 32nd & 9.79 & 37 th & 5.18 & \\
\hline a. Technical worker & 62 & 5.95 & $31 \mathrm{st}$ & 9.48 & $31 \mathrm{st}$ & 4.34 & \\
\hline b. Manager & 7 th & 0.67 & $1 \mathrm{st}$ & 0.31 & 6th & 0.84 & \\
\hline CHRONIC DISEASE & 963 & & 312 & & 651 & & 0.654 \\
\hline No & 547 & 56.80 & 174 & 55.77 & 373 & 57.30 & \\
\hline Yes & 416 & 43.20 & 138 & 44.23 & 278 & 42.70 & \\
\hline $\begin{array}{l}\text { OCCUPATIONAL ACCIDENT IN THE LAST } \\
\text { YEAR (March 2019-March 2020) }\end{array}$ & 1043 & & 328 & & 715 & & 0.948 \\
\hline No & 851 & 81.59 & 268 & 81.71 & 583 & 81.54 & \\
\hline Yes & 192 & 19.77 & 60 & 18.29 & 132 & 18.46 & \\
\hline TRAINING IN THE LAST YEAR (2019) & 1043 & & 328 & & 715 & & 0.319 \\
\hline No & 933 & 89.45 & 298 & 90.85 & 635 & 88.81 & \\
\hline Yes & 110 & 10.55 & 30th & 9.15 & 80 & 11.19 & \\
\hline SOURCE OF CONTACT & 1040 & & 327 & & 713 & & $<0.001$ \\
\hline Patient & 469 & 45.10 & 62 & 18.96 & 407 & 57.08 & \\
\hline Nonhospital & 30 & 2.88 & 22 & 6.73 & 8 & 1.12 & \\
\hline Healthcare worker & 541 & 52.02 & 243 & 74.31 & 298 & 41.80 & \\
\hline CONTACT LOCATION & 1027 & & 325 & & 702 & & $<0.001$ \\
\hline COVID-19 clinic & 380 & 37.00 & 111 & 34.15 & 269 & 38.3 & \\
\hline Non-COVID-19 clinic & 526 & 51.22 & 145 & 44.62 & 381 & 54.3 & \\
\hline Other hospital areas & 121 & 11.78 & 69 & 21.23 & 52 & 7.4 & \\
\hline NUMBER OF CONTACTS & 1042 & & 327 & & 715 & & 0.003 \\
\hline First contact & 836 & 80.23 & 280 & 85.63 & 556 & 77.76 & \\
\hline Repeated & 206 & 19.77 & 47 & 14.37 & 159 & 22.24 & \\
\hline
\end{tabular}

* There are missing data for some variables. ${ }^{*}$ Percentage of columns 
Table-2. Factors associated with high-risk contacts of healthcare workers with corrected analysis.

\begin{tabular}{|c|c|c|c|c|c|c|c|}
\hline & \multirow[b]{2}{*}{ CHARACTERISTICS } & & \multirow[b]{2}{*}{$\mathrm{n}$} & \multirow[b]{2}{*}{$\%$} & \multicolumn{3}{|c|}{ High-risk exposure } \\
\hline & & & & & OR & & $\mathrm{Cl}$ \\
\hline \multirow[t]{3}{*}{ Contact location } & COVID-19 clinics & Ref & 111 & 29.21 & & & \\
\hline & Non-COVID-19 clinics & & 145 & 27.57 & $1.57^{\star}$ & 1.10 & 2.22 \\
\hline & Non-clinical areas & & 69 & 57.02 & $2.20^{\star}$ & 1.22 & 3.96 \\
\hline \multirow[t]{3}{*}{ Contact source } & Patient & Ref & 62 & 13.22 & & & \\
\hline & Out-of-hospital & & 22 & 73.33 & $13.34^{\star \star}$ & 5.24 & 33.96 \\
\hline & Healthcare worker & & 243 & 44.92 & $5.78^{\star \star}$ & 4.07 & 8.20 \\
\hline \multirow[t]{3}{*}{ Service delivered } & Healthcare services & Ref & 179 & 26.8 & & & \\
\hline & Healthcare support services & & 113 & 37.05 & $1.80^{\star}$ & 1.27 & 2.56 \\
\hline & Technical services & & 31 & 44.93 & 1.24 & 0.60 & 2.57 \\
\hline \multirow[t]{2}{*}{ Number of contacts } & Repeated & Ref & 280 & 33.49 & & & \\
\hline & First contact & & 47 & 22.82 & $1.56^{\star}$ & 1.04 & 2.34 \\
\hline
\end{tabular}

Percentage of rows, ${ }^{*} p<0.05$ and ${ }^{* *} p<0.00$, Nagelkerke R Square: 0.224

\section{DISCUSSION}

In this study, which aimed to determine the risk level of contacts between employees at EUMF Hospital, Izmir, and COVID-19-positive cases between March 11 and May 31, 2020, and to reveal the factors associated with high-risk contact, the proportion of healthcare workers with high-risk exposure was found to be $31.45 \%$. Clinics not related to COVID-19 and other nonclinical hospital areas as contact location variable; contact with healthcare workers and nonhospital sources as contact source variable; provision of healthcare support services as a variable of the type of healthcare service delivery; and first contacts as the number of contacts variable were found to be associated with the high-risk exposure group.

\section{Characteristics of the group with contact}

Within the scope of this study, the mean age of the EUMF healthcare workers who had contact with COVID-19-positive cases was 35.80 years; $57.43 \%$ of the healthcare workers who contacted patients with COVID-19 were female, $24.95 \%$ were physicians, $19.77 \%$ were nurses, and $29.27 \%$ were healthcare support workers, who all provided frontline healthcare services. Although the number of similar studies is limited, in a study evaluating 7-day exclusion of healthcare workers due to contact with COVID-19-positive patients during the pandemic in Greece, the group with contact was found to be in a similar age group and have a similar sex distribution (age, 44.5 years and $61 \%$ women) as the present study, but the occupation that had contact exposure was mainly the nurses (31.8\% physicians, $50.2 \%$ nurses, and $3.3 \%$ support workers) (18). In a study that monitored healthcare workers who had contact with a COVID-19-positive patient at a hospital in California, $84 \%$ of 43 healthcare workers were female and $51 \%$ were nurses (18). In both of the abovementioned examples, the prevailing sex was female among the healthcare workers who had contact with COVID-19-positive patients, similar to the findings of the present study. Organizational differences in the delivery of healthcare services can explain the differences in age, sex, and occupational distribution. The fact that nurses are mainly women plays an important role in sex distribution. SARS-CoV-2 has usually affected people older than 50 years, and deaths are rare among infected healthcare workers who have a lower mean age (20). Low mean age can be explained by early isolation of the older employees who are at risk as a precaution.

In this study, the proportion of healthcare workers who had high-risk exposure was found to be $31.45 \%$, whereas $12 \%$ of the healthcare workers were found to have high-risk exposure in a study 
evaluating 43 healthcare workers who contacted a single positive case in California. In another more extensive study conducted with 3398 healthcare workers who had contact with a COVID-19-positive patient, 1031 (30.4\%) workers were found to have high-risk exposure, which is more parallel to the results of our study. While approaching the sufficient sample size, it was observed that one in three healthcare workers who had contact with a COVID-19-positive patient was included in the high-risk group that would require at least 7 days of isolation $(18,19)$.

\section{Location of contact}

In this study, which was conducted at a university hospital, taking COVID-19 clinics as a reference, other clinics that did not involve patients with COVID-19 and other hospital areas outside the clinics were found to pose 1.57-fold higher and 2.20-fold higher risk of exposure to COVID-19, respectively. In the Greece example, the majority of healthcare workers who had contact exposure worked in hospitals, especially in the internal medicine departments (1368; 40.2\%). Working in the internal medicine departments has a higher potential of high-risk contact for healthcare workers than working in the emergency or intensive care units (19). Healthcare workers are more careful in terms of PPE and safe distance in hospital areas where the perceived risk of COVID-19 transmission is high, whereas they might be less careful in clinics where follow-up for patients with COVID-19 is not performed and in nonclinical work environments. The presence of symptomatic or oligosymptomatic healthcare workers infected with SARS-CoV-2 makes break rooms and training meetings riskier in terms of contact along with no use of PPE (20).

\section{Contact source}

In this study, the risk of contact with other healthcare workers was 5.78 times higher and the risk of contact with nonhospital sources was 13.34 times higher for healthcare workers, taking contact with patients as a reference. Depending on the stage of the pandemic, because of strong infection control measures, patients with COVID19 may not be the main source of SARS-CoV-2 infection, and healthcare workers can be exposed to atypical patients, infected family members and colleagues (20). Considering the difficult working conditions, contacts between healthcare workers and atypical, asymptomatic patients and colleagues are among the risks that should be carefully monitored (22). Contact between family members living in the same house can lead to prolonged and frequent contact exposure in the same place with the same people (21). Having a family member with COVID-19 in addition to incorrect PPE use and inadequate infection control measures can lead to 2.8-fold increased risk of SARS-CoV-2 infection among healthcare workers (14).

\section{Services delivered}

In this study conducted at a university hospital, healthcare workers who provided healthcare support services had 1.80 -fold higher risk than those who provided frontline healthcare services (physicians and nurses). In the Greece example, administrative staff made higher risk contacts than physicians and nurses who provided frontline services (19). It is possible to say that, among healthcare workers who are particularly included in the high-risk contact group since they provide direct treatment or transport services to the patients, physicians and nurses adapt to the use of PPE within a shorter period of time, whereas support workers who need to enter the patients' rooms and administrative staff who do not encounter patients directly avoid wearing surgical masks $(19,22)$. Especially in this group, these results point out the training need for PPT usage and supervision about infection control procedures.

\section{Number of contacts}

Healthcare workers who had the first risky contact were considered to have 1.56-fold higher risk-contact than those who had repeated exposure. Repeated contact can be explained by patient density that could lead to exposure of the healthcare worker within a short time period, whereas the decrease in high-risk contacts with increased number of contacts can be considered as an indicator that healthcare workers have improved themselves in terms of the use of PPE and infection control measures during the pandemic.

\section{Limitations}

Chronic disease data was obtained from hospital records and belongs to 2019; thus, the current condition can be different. There is a need for further studies with a larger population investigating out-of-hospital contacts with COVID-19 among healthcare workers. 


\section{CONCLUSION}

At EUMF Hospital, İzmir, the contact of approximately one in three healthcare workers with COVID-19-positive cases was found to be high-risk contact. Contrary to what's expected, non-clinical areas, social relations, contacts between healthcare workers who do not provide frontline healthcare services involved a higher risk. The fact that high-risk contact was less common among the sites that provide frontline COVID-19 treatment services and healthcare workers that provide frontline patient care for COVID-19 compared with that among other settings and individuals can be interpreted as an indicator that healthcare workers have improved themselves in terms of the use of PPE and infection control measures during the pandemic.

\section{Abbreviations}

COVID-19: Coronavirus disease 2019

ÇASAGÜB: Occupational Health and Safety Unit

EUMF: Ege University Medical Faculty

PPE: Personal protective equipment

SARS-CoV-2: Severe acute respiratory syndrome coronavirus 2

WHO: World Health Organization

\section{Acknowledgements}

We would like to thank all physicians and ÇASAGÜB employees who took part in the EUMF Hospital Surveillance Team during the pandemic period for their contribution.

Conflict of Interests: The authors declare no competing interests.

\section{References}

1. Republic of Turkey Ministry of Health. COVID-19 Guides [Internet]. Vol. 1 June. 2020 [cited 2020 Aug 12]. Available from: https://hsgm.saglik.gov.tr/en/covid-19-i-ngilizce-dokumanlar/rehberler.html

2. European Centre for Disease Prevention and Control. Contact Tracing: Public Health Management of Persons, Including Healthcare Workers, Having Had Contact with COVID-19 Cases in the European. Stokholm; 2020.

3. Heneghan C, Oke J, Jefferson T. COVID-19 How many Healthcare workers are infected? - CEBM [Internet]. 2020 [cited 2020 Aug 8]. Available from: https://www.cebm.net/covid-19/covid-19-how-many-healthcareworkers-are-infected/

4. Kluytmans-van den Bergh, M., Buiting, A., Pas, S. D., Bentvelsen, R. G. et al. (2020). Prevalence and Clinical Presentation of Health Care Workers With Symptoms of Coronavirus Disease 2019 in 2 Dutch Hospitals During an Early Phase of the Pandemic. JAMA network open, 3 (5), e209673. https://doi.org/10.1001/jamanetworkopen.2020.9673

5. Xiaoquan Lai, MD1; Minghuan Wang, MD, PhD2; Chuan Qin, MD, PhD2 et al. (2020) Coronavirus Disease 2019 (COVID-2019) Infection Among Health Care Workers and Implications for Prevention Measures in a Tertiary Hospital in Wuhan, China. JAMA Netw open. 3 (5): e209666.

6. Arslan GK, Özdemir M, Feyzioğlu B, Kurt E, Eray I (2020). Results of SARS-COV-2 Rapid Antibody Tests and ELISA Antibody Tests in Healthcare Workers in Our Hospital. In: COVID19 Symposium. Sakarya.

7. NSW Government (2020). Nosocomial COVID-19 infections, Evidence Check.

8. CDC (2020). Interim Operational Considerations for Public Health Management of Healthcare Workers Exposed to or with Suspected or Confirmed COVID-19: non-U.S. Healthcare Settings [Internet]. [cited 2020 Aug 9]. Available from: https://www.cdc.gov/coronavirus/2019-ncov/hcp/non-us-settings/public-healthmanagement-hcw-exposed.html

9. European Centre for Disease Prevention and Control. Contact tracing: public health management of persons, including healthcare workers, who have had contact with COVID-19 cases in the European Union - third update, 18 November 2020. Stockholm: ECDC; 2020

10. CDC. Appendix 1: Risk Assessment for Healthcare Workers Exposed to Persons with COVID-19. 2019; 1-3.

11. Republic of Turkey Ministry of Health April 2020. Assessment of Healthcare Staff with COVID-19 Contact 09.04.2020. 
12. World Health Organization. Report of the WHO-China Joint Mission on Coronavirus Disease 2019 (COVID19). Vol. 2019, The WHO-China Joint Mission on Coronavirus Disease 2019. 2020.

13. Wu Y, Song S, Kao Q, Kong Q, Sun Z, Wang B (2020). Risk of SARS-CoV-2 infection among contacts of individuals with COVID-19 in Hangzhou, China. Public Health;185:57-9.

14. Ran L, Zhang L, Wu W, Tan X, Chen X, Wang Y (2020). Risk Factors of Healthcare Workers With Corona Virus Disease 2019: A Retrospective Cohort Study in a Designated Hospital of Wuhan in China - PubMed. Clin Infect Dis.

15. Chen, Y., Tong, X., Wang, J. et al. (2020). High SARS-CoV-2 antibody prevalence among healthcare workers exposed to COVID-19 patients. The Journal of infection, 81 (3), 420-426. https://doi.org/10.1016/j.jinf.2020.05.067

16. World Health Organization (May 10,2020). Contact tracing in the context of COVID-19. WHO Guideline. 1-7.

17. CDC (2020). Interim U.S. Guidance for Risk Assessment and Work Restrictions for Healthcare Personnel with Potential Exposure to COVID-19 | CDC [Internet]. [cited 2020 Aug 10]. Available from: https://www.cdc.gov/coronavirus/2019-ncov/hcp/guidance-risk-assesment-hcp.html

18. Heinzerling A, Stuckey MJ, Scheuer T. et al. (April, 2020). Transmission of COVID-19 to Health Care Personnel During Exposures to a Hospitalized Patient - Solano County, California, February 2020. MMWR Morb Mortal Wkly Rep. 17; 69 (15): 472-476. doi: 10.15585/mmwr.mm6915e5. PMID: 32298249; PMCID: PMC7755059.

19. Maltezou, H. C., Dedoukou, X., Tseroni, M. et al. (2020). SARS-CoV-2 infection in healthcare personnel with high-risk occupational exposure: evaluation of seven-day exclusion from work policy. Clinical infectious diseases: an official publication of the Infectious Diseases Society of America, ciaa888. Advance online publication. https://doi.org/10.1093/cid/ciaa888

20. Bielicki, J. A., Duval, X., Gobat, N. et al.(2020). Monitoring approaches for health-care workers during the COVID-19 pandemic. The Lancet Infectious Diseases, 20 (10). https://doi.org/10.1016/S1473-3099 (20) 30458-8

21. L., Huang, M., Chen, M., Tan, C., et al.(2020). Household Transmission of SARS-CoV-2, Zhuhai, China, (2020). Clinical infectious diseases: an official publication of the Infectious Diseases Society of America, 71 (16), 2099-2108. https://doi.org/10.1093/cid/ciaa557

22. OSHA. Guidance on Preparing Workplaces for COVID-19. 2020. 